an important role in the release of beta-lipoprotein in fatty liver induced by a low-protein diet.

Thus, the present work demonstrates that phospholipid has a curative effect on experimental fatty liver and that the effect is due to the release of lipoprotein from the liver.

\title{
REFERENCES
}

1) Rouller, C.H.: The Liver, Editcd by Rouller, C.H., Vol, 2, p. 394, Academic Press, Nicw York and London (1964); 2) Shaplro, B.: Lipids and Lipidoses, Edited by ScheTtLriR, G., p. 52, Springer-Verlag, Berlin, Ileidelberg, and New York (1967); 3) I.AMBord, B.: Fein. Proc. 24, 1200 (1965); 4) Handschmachlik, R.E., Crfasey, W.A., Jaffl, J.I., Pastriknak, C.A., and Hankin, L.: Proc, natm. Acad. Sci, 46, 128 (1960); 5) Marinvitti, G.Y., Ermland, J., and Kochey, J.: Fedh. Proc., 16, 837 (1957); 6) Kotaki, A., Sakurat, T., Orumura, M., AND Yagi, K.: Vitamin.s, 39, 168 (1969); 7) Yagi, K., AND Kotaki, A.: Anm. N.Y. Acal. Sci, 165.710 (1969); 8) llasat, S.11., Nakagawa, Y., Nishigaki, l., And Yagi, K.: J. Vitaminol., 17, 159 (1971)

\section{URINARY EXCRETION PATTERNS OF MORPHINE IN HUMANS FOLLOWED BY AN RADIOIMMUNOASSAY METHOD}

\author{
Masakalsu TAKAHASHI, Masao KOIDA, Hiroshi KANETO, \\ Yutaka GOTO* and Sumitaka HASEBA* \\ Department of Plarmacology, Faculty of Pharmaceutical Sciences, Nagasaki University, \\ Bunkyo-machi, Nugusahi and *Department of Anesthesiology, School of Medicine. \\ Nagasaki University, Sakamoto-machi, Nagasahi, Japan
}

Accepted Fcbruary 10, 1975

Recently, morphine was added to the list of compounds which can be detected in biological fluid by radioimmunonsay methods (1-4). Production and the specificity test of the antibodies directed to three morphine derivatives have led to development of radioimmunoassay of morphine by the usc of morphine 3-glucuronide (M-3-G) directed antibody (5). In the present experiment, applicability of the method for clinical use was tested.

Morphine $\mathrm{HCl}$ was injected i.v. into five humans as the basal anesthetic in doses of 10 to $50 \mathrm{mg} /$ patient and thereafter $24 \mathrm{hr}$ urine samples were collected for onc week. During the experimental period, other drugs known to interfere the binding of morphine to the antibody were not ingested. The sample was stored below $20 \mathrm{C}$ before analysis and the radioimmunoassay of morphine was carried out as previously described (5). Before analysis, the urine sample was warmed to room temperature and the supernatant analyzed. The quantity of the drug in an aliquot $(100 / 1)$ of the sample or of its dilution up to 50 fold, was read off by a standard curve run for $\mathrm{M}-3-\mathrm{G}$ in the presence of the corresponding amount of normal urine, as the urine contained the interfering factor(s).

Results are shown in Table 1. On the average, more than half of the drug was recovered in the first sample. For the next 4 days, the excretion of the drug was deteclable in all cases and in two for an additional two days. The results parallel those found in 
TABIF I. Analyses of urine samples from humans on morphine

\begin{tabular}{|c|c|c|c|c|c|}
\hline $\begin{array}{l}\text { Utine } \\
\text { collection } \\
\text { (hr) }\end{array}$ & 10 $\mathrm{A}$ & $\begin{array}{c}\mathrm{B} \\
20 \mathrm{ng}\end{array}$ & $\begin{array}{c}C \\
30 \mathrm{mg}\end{array}$ & $\begin{array}{c}\mathrm{D} \\
40 \mathrm{mg}\end{array}$ & E \\
\hline $0-24$ & $\begin{array}{r}* 5.334 \quad(53.3) \\
* * 3810\end{array}$ & $\begin{array}{r}12.407 \\
2385\end{array}$ & $\begin{array}{l}8.775 \\
975\end{array}(29.3)$ & $\begin{array}{c}26.100(65.3) \\
1450\end{array}$ & $\begin{array}{l}35.100(70.2) \\
1190\end{array}$ \\
\hline $24-48$ & $\begin{array}{c}0.525 \\
2500\end{array}$ & $\begin{array}{r}0.500 \\
2500\end{array}(2.5)$ & $\begin{array}{c}2.880 \\
2400\end{array}(9.6)$ & $\begin{array}{r}2.220 \\
1900\end{array}$ & $1.720(3.4)$ \\
\hline $48-72$ & $\begin{array}{l}0.870(8.7) \\
1350\end{array}$ & $0.189(0.9)$ & $1.163(3.9)$ & $\begin{array}{r}2.090(5.2) \\
2020\end{array}$ & $0.250(0.5)$ \\
\hline $72 \cdot 96$ & $\begin{array}{r}0.350(3.5) \\
1100\end{array}$ & $\begin{array}{r}0.902(4.5) \\
1100\end{array}$ & $\begin{array}{r}0.920 \\
1550\end{array}(3.1)$ & $\begin{array}{l}1.130(2.8) \\
1580\end{array}$ & $\begin{array}{c}0.151 \\
1080\end{array}$ \\
\hline $96 \cdots 120$ & $0.260(2.6)$ & $\frac{0.243}{930}(1.2)$ & $\begin{array}{r}0.549 \\
1100\end{array}(1.8)$ & $\begin{array}{l}0.702 \\
1130\end{array}(1.8)$ & $\begin{array}{l}0.077(0.2) \\
1100\end{array}$ \\
\hline $120-144$ & $\begin{array}{c}0.084 \\
1200\end{array}$ & $\begin{array}{l}0.000(0.0) \\
1400\end{array}$ & $\begin{array}{l}0.051 \\
1500\end{array}(0.2)$ & $\begin{array}{l}0.426(1.1) \\
1350\end{array}$ & $\begin{array}{l}0.000(0.0) \\
1800\end{array}$ \\
\hline $144-168$ & $\begin{array}{c}0.000 \\
1750\end{array}(0.0)$ & $\begin{array}{l}0.000 \\
1450\end{array}(0.0)$ & $\begin{array}{l}0.045 \\
900\end{array}(0.2)$ & $0.124(0.3)$ & $\begin{array}{l}0.000 \\
2600\end{array}(0.0)$ \\
\hline $0-168$ & $7.423(74.2)$ & $14.241(71.2)$ & $14.383(47.9)$ & $32.792(82.0)$ & $37.298(74.6)$ \\
\hline
\end{tabular}

* indicates the amounts of morphine 3-glucuronide and free morphine (ng). Figures in parentheses indicate the amount of the drugs as a percent of the dose.

**: Urine volume (ml).

Patients: A-.-Myoma of uterus, B-Gallstones, C.- Pancrealic cancer. The bile was conducted outside for surgical purpose. D-Uterine cancer and E-..Aortic insufficiency.

rats in which $10 \mathrm{mg} / \mathrm{kg}$ of morphine or codeine was given and the drug was detectable for at least five days after the administration even without manipulation of the sample (5). The drug excreted in urine from humans was in a more diluted concentration than that in the rat. However, peculiar excretion patterns were seen in urine from patients A, B. There was a second peak in the pattern, which never had appeared after administration of either dihydrocodeine to healthy adults or morphine to rats (5). The rigid specificity of the M3-G antibody excludes the possibility that the other agents ingested by the patients could produce a false pattern by interfering with the morphine-antibody binding. In fact, the urine of the volunteers to whom an anti-inflammatory drug with high binding affinity to serun protein had been given, exhibited no inhibitory influence on the morphine-antibody binding (unpublished data). Therefore, such a peculiar excretion pattern may be attributed to abnormal conditions such as depressed function of the internal organs, venous hyperemia following surgery, etc.

The radioimmunoassay method can indeed be applied to determine the excretion levels of a drug, and our results herein suggest that development of methods for other therapeutics would lead not only to a re-evaluation of the drugs themselves but could be utilized as a diagnostic indicator of the physiological conditions involved.

\section{REFERENCES}

1) Splcior, S.: J. Pharmacol. exp. Ther. 178, 253 (1971): 2) Splctor, S. And Vesfi.t, F.S.: Science 174, 421 (1971): 3) Van Vunakis, H., Wasserman, E. And Levine, L.: J. Pharmacol. exp. Ther. 180, 514 (1972): 4) Catlin, D., Ciffland, R. ard Girlnberg, E.: Clin. Chem. 19, 216 (1973): 5) Koldu, M., Takalashi, M. and Kanlto, H.: Japan. J, Pharmacol. 24, $707(1974)$ 